\title{
Epididymal morphophysiology of adult collared peccaries (Pecari tajacu)
}

\author{
Morfofisiologia epididimária de catitus (Pecari tajacu) adultos \\ Anna Patrycia Martins de OLIVEIRA ${ }^{1}$; Deise de Lima CARDOSO ${ }^{1}$; Ana Cássia Sarmento \\ FERREIRA ${ }^{2}$; Maria Auxiliadora Pantoja FERREIRA ${ }^{3}$; Natália Inagaki de ALBUQUERQUE; ${ }^{4}$ Otávio Mitio \\ OHASHI $^{1}$; Diva Anelie GUIMARÃES ${ }^{1}$
}

\author{
${ }^{1}$ Universidade Federal do Pará, Instituto de Ciências Biológicas, Laboratório de Reprodução Animal, Belém - Pará, Brazil \\ ${ }^{2}$ Instituto Federal do Pará, Belém - Pará, Brazil \\ ${ }^{3}$ Universidade Federal do Pará, Instituto de Ciências Biológicas, Laboratório de Técnicas Histológicas, Belém - Pará, Brazil \\ ${ }^{4}$ Embrapa Amazônia Oriental, Belém - Pará, Brazil
}

\begin{abstract}
A functional understanding of the epididymis makes it possible to increase a species' fertility, since it facilitates the preservation of gametes for use in assisted reproduction techniques. This study analyzed the histological features of the different regions of the epididymis of the Pecari tajacu and the associated pathologies found in the spermatozoa present in this organ. After an orchiectomy surgery to remove the testicles and epididymis obtained from eight adult animals bred in captivity, fixation and histological processing of samples were carried out. The presence of pseudostratified columnar epithelium with stereocilia was observed in all regions of the epididymis (caput, corpus and caudal). Similarities were noted between the average height of the corpus and caudal epithelium, which differed from that found at the caput (1- proximal: region associated with the efferent ducts; 2- distal: region associated with corpus epididymis). It was also observed that the proximal caput presents a smaller average of the tubules diameter compared to other portions of the epididymis. Regarding pathologies of the spermatozoa, thirteen different types of morphological modifications were observed. Underdeveloped spermatozoa and detached heads were most frequently encountered along the epididymis of the collared peccaries. This study is a pioneer in the area and its data will serve as a basis for comparative research on the reproductive biology of artiodactyls, thus contributing to their conservation and reproduction.
\end{abstract}

Keywords: Epididymis. Spermatozoon. Histology. Morphology. Pecari tajacu.

\section{Resumo}

O entendimento funcional do epidídimo possibilita o aumento da fertilidade de uma espécie, pois torna possível a preservação de gametas para o uso em técnicas de reprodução assistida. Este trabalho estudou os aspectos histológicos das diferentes regiões do epidídimo de Pecari tajacu, bem como as patologias associadas encontradas nos espermatozoides presentes nesse órgão. Após procedimento cirúrgico de orquiectomia, para remoção dos testículos e epidídimos, obtidos de oito animais adultos nascidos em cativeiro, realizou-se a fixação e o processamento histológico das amostras. Constatou-se em todas as regiões do epidídimo (cabeça, corpo e cauda) a presença de epitélio pseudoestratificado colunar com estereocílios. Foram observadas semelhanças entre a altura média do epitélio do corpo e da cauda, a qual era diferente da encontrada na cabeça (1- proximal: região associada aos ductos eferentes; 2 - distal: região associada ao corpo do epidídimo). Foi verificado que a cabeça proximal apresenta a média de diâmetro dos túbulos menor em relação às demais porções do epidídimo. Em relação às patologias dos espermatozoides, constataram-se treze tipos diferentes de alterações morfológicas. Os espermatozoides subdesenvolvidos e cabeças soltas foram as mais frequentes ao longo do epidídimo de catitus. Os dados deste trabalho são pioneiros, e servirão como base para pesquisas comparativas sobre a biologia reprodutiva dos artiodátilos, contribuindo para a sua conservação e produção.

Palavras-chave: Epidídimo. Espermatozoide. Histologia. Morfologia. Pecari tajacu. 
Correspondence to:

Deise de Lima Cardoso

Universidade Federal do Pará, Instituto de Ciências Biológicas, Laboratório de Reprodução Animal

Rua Augusto Corrêa, 1 - Guamá

CEP 66075-110, Belém, Pará, Brazil

e-mail: deisecardosomv@yahoo.com.br

Received: $15 / 12 / 2015$

Approved: 30/08/2016

\section{Introduction}

The collared peccary (Pecari tajacu) is part of the Tayassuidae, along with two other species, the whitelipped peccary (Tayassu pecari) and the chacoan peccary (Catagonus wagneri), which belongs to the suborder Suiformes (SOWLS, 1997). This species is found from the South of the United States of America to the North of Argentina. It may occupy various habitats, from humid tropical forests to savannahs and deserts (SOWLS, 1997). The destruction of its habitat and hunting are the main threats to its conservation in Brazil (DESBIEZ et al., 2012). The reproductive success of wild species is directly related to their ability to overcome the factors that decrease their populations (BODMER; PUERTAS, 2000; MAYOR et al., 2006). Thus, research on reproductive functions becomes fundamental for the establishment of appropriate animal management systems.

The epididymis is a structure located between the efferent and deferent ducts, and consists of a coiled tube connected to the testicle, which makes it a male reproductive organ (SULLIVAN, 2004). Its main functions are: transportation, development of motility and fertilizing ability of the spermatozoa, and creation of a luminal environment, specialized in the conduction of the epithelial maturation and functionality process (ROBAIRE et al., 2006). A functional understanding of the epididymis makes it possible to expand a species' fertility, since it increases the opportunity for preservation of gametes which are essential in assisted reproduction techniques.

Regarding the reproductive physiology of male collared peccaries, Hellgren et al. (1995); Carvalhal et al. (2000); Sonner et al. (2004); Kahwage et al. (2010) and Garcia et al. (2012), among other authors, observed some andrological aspects, such as: levels of testosterone, testicular biometrics and semen analysis. However, no previous research studied histopathological characteristics of spermatozoa from the epididymis of this species.

Therefore, the aim of the present study was to analyze the histological features of different regions of the P. tajacu epididymis and the associated pathologies found in spermatozoa present in this organ.

\section{Material and Methods}

\section{Animals and management}

Eight captive-bred adult male P. tajacu, with ages ranging from two to four years, from the scientific research breeding facility of Embrapa Eastern Amazon, (IBAMA 1501.5219/2011-PA), located in Belém, State of Pará, Brazil $\left(01^{\circ} 24^{\prime} S\right.$; $\left.48^{\circ} 20^{\prime} \mathrm{W}\right)$ were analyzed. During the experimental period, the animals were housed in five collective pens of $36 \mathrm{~m}^{2}$, in a concrete floored pen provided with feeders and water troughs within the same building.

Animals were fed once a day on a diet of Napier grass (Pennisetum purpureum) and commercial swine feed $(2.500 \mathrm{Kcal} / \mathrm{kg}$ and $14 \%$ Crude Protein).

\section{Epididymis Collection}

The animals were anesthetized with ketamine chloridate $(5 \mathrm{mg} / \mathrm{kg})$ and $0.2 \%$ acepromazine $(0.2$ $\mathrm{mg} / \mathrm{kg}$ ), and subjected to bilateral orchiectomy. Harvesting of the epididymis samples occurred after surgery (Figure 1), with immediate transportation to the Animal Reproduction Laboratory of the Universidade Federal do Pará, in refrigerated phosphate-buffered saline (PBS) solution. The experiments performed were approved by the Ethical Committee for Animal Research, Universidade Federal do Pará (Authorization number CEPAE 184-13), and were conducted in compliance with current Brazilian and international laws on the use of animals for research purposes. 




Figure 1 - P. tajacu epididymis, anatomically divided into following regions: caput $(*)$, corpus $(\boldsymbol{\Delta})$ and caudal $(\triangleright)$, connected to the testicle

Each of the four parts of the epididymis (1proximal caput: region associated with the efferent ducts, 2- distal caput: region associated to corpus epididymis, 3- corpus and 4- caudal) was divided into two portions; one portion was macerated (OLUGBENGA; ONIOVOSA, 2005), while the other was left intact. The caudal epididymis, however, was not macerated, since it was submitted to the retrograde flux technique (KIKUCHI et al., 1998).

The macerated portions and the cellular samples from caudal epididymis were placed in saline formaldehyde ( $96 \mathrm{ml}$ of $2.9 \%$ sodium citrate and $4 \mathrm{ml}$ of $4 \%$ formaldehyde), and then stored at $5^{\circ} \mathrm{C}$. They were used for spermatozoa morphological analysis, according to Blom (1973). For this analysis, 200 cells per slide were counted. Slides were prepared with humid drops, and amplified to $1000 \mathrm{X}$ by phase contrast optic microscope.

The intact portions were wrapped in gauze, identified and fixated in ALFAC solution ( $85 \mathrm{ml}$ of $80 \%$ alcohol, $10 \mathrm{ml}$ formaldehyde and $5 \mathrm{ml}$ acetic acid). The samples were stored at $5^{\circ} \mathrm{C}$ for 24 hours; after this period, they were submitted to routine histological processing. Posteriorly, histology sections $5 \mu \mathrm{m}$ were stained with hematoxylin and eosin. After staining and mounting, the slides were analyzed with optical microscopy. To compare the regions comprising the epididymis, the diameter of 20 tubules of each segment of epididymis/animal was measured, as well as the height of the epithelium up to 30 tubules for each region/animal.

\section{Statistical analyses}

This study used parameters of descriptive statistical analyses such as average and standard deviation, as well as the ANOVA variance test (one-way) and the posthoc Newman-Keuls test. The non-parametric MannWhitney $U$-test was used to compare two categories: major and minor defects in each region. The tests contemplate quantification and classification of epididymal pathologies, occurring in each region of the epididymis, as well as the morphometric comparison among the diameter $(\mu \mathrm{m})$ and height of the epithelium $(\mu \mathrm{m})$ of the epididymal tubules, according to each part. The confidence level of probability adopted was $5 \%$ and the results were analyzed using Statistica software, version 7.0.

\section{Results}

Comparison of the diameters of the tubules with the ANOVA test (one-way) identified differences $(\mathrm{P}<$ 0.05) among the regions of the epididymis of the studied animals. Posterior comparisons (NewmanKeuls test) indicated differences $(\mathrm{P}<0.05)$ between the diameters of tubules from proximal and distal caput; proximal caput and corpus; proximal caput and caudal. However, there was no significant difference $(\mathrm{P}>0.05)$ in the diameter of the tubules regarding the other three regions of the epididymis (Table 1).

Table 1 - Mean and standard deviation $(\mu \mathrm{m})$ of the diameter of the tubules from each region of the $P$. tajacu epididymis. Belém, Pará - Brazil -2015

\begin{tabular}{ccc}
\hline $\begin{array}{c}\text { Regions of the } \\
\text { epididymis }\end{array}$ & Mean $\pm \mathrm{SD}(\mu \mathrm{m})$ & $\begin{array}{c}\text { Total of analyzed } \\
\text { tubules }\end{array}$ \\
\hline Proximal caput & $32.23 \pm 17.54^{\mathrm{a}}$ & 41 \\
Distal caput & $61.72 \pm 26.57^{\mathrm{b}}$ & 60 \\
Corpus & $61.07 \pm 23.78^{\mathrm{b}}$ & 80 \\
Caudal & $54.61 \pm 16.64^{\mathrm{b}}$ & 80 \\
\hline
\end{tabular}

$\overline{a, b}$ different letters in the same column indicate significant statistical difference $(P<0.05)$ 
Regarding comparisons of height of the epithelium of the epididymal tubules (ANOVA test one-way), significant differences were verified (Table 2). Posterior comparisons (Newman-Keuls test) indicated significant differences $(\mathrm{P}<0.05)$ between the proximal caput and corpus; proximal caput and caudal; distal caput and proximal caput; distal caput and corpus; distal caput and caudal. No significant differences $(\mathrm{P}>$ 0.05) were observed between the epithelium of the corpus and the caudal epididymis, which can be observed in Table 2, below.

Table 2 - Mean and standard deviation of height of the epithelium $(\mu \mathrm{m})$ from the different regions of the $P$. tajacu epididymis. Belém, Pará - Brazil - 2015

\begin{tabular}{|c|c|c|}
\hline $\begin{array}{c}\text { Regions of the } \\
\text { epididymis }\end{array}$ & Mean $\pm S D(\mu m)$ & $\begin{array}{c}\text { Total of analyzed } \\
\text { tubules }\end{array}$ \\
\hline Proximal caput & $22.45 \pm 12.15^{a}$ & 60 \\
\hline Distal caput & $38.88 \pm 18.40^{b}$ & 90 \\
\hline Corpus & $49.32 \pm 24.95^{c}$ & 150 \\
\hline Caudal & $47.47 \pm 21.12^{c}$ & 119 \\
\hline
\end{tabular}

$a, \overline{b, c}$ different letters in the same column indicate significant statistical difference $(P<0.05)$
In all the regions of the $P$. tajacu epididymis, columnar pseudostratified epithelium with stereocilia, smooth muscle and loose connective tissue in the intertubular space were observed. However, histological differences were verified between the regions.

The shape of the tubules showed modifications along the epididymis. Tubules on the proximal caput epididymis, as well as presenting smaller diameters and epithelium height, with long stereocilia, presented narrow lumen with few spermatozoa (Figure 2A), when compared to the other regions. The epididymal tubules on the distal caput and corpus had larger diameters and an elongated shape (Figures 2B and 2C). On the caudal epididymis, tubules were more rounded or oval (Figure 2D), and the lumen area was broader and well defined, with the presence of shorter stereocilia and a large quantity of spermatozoa.

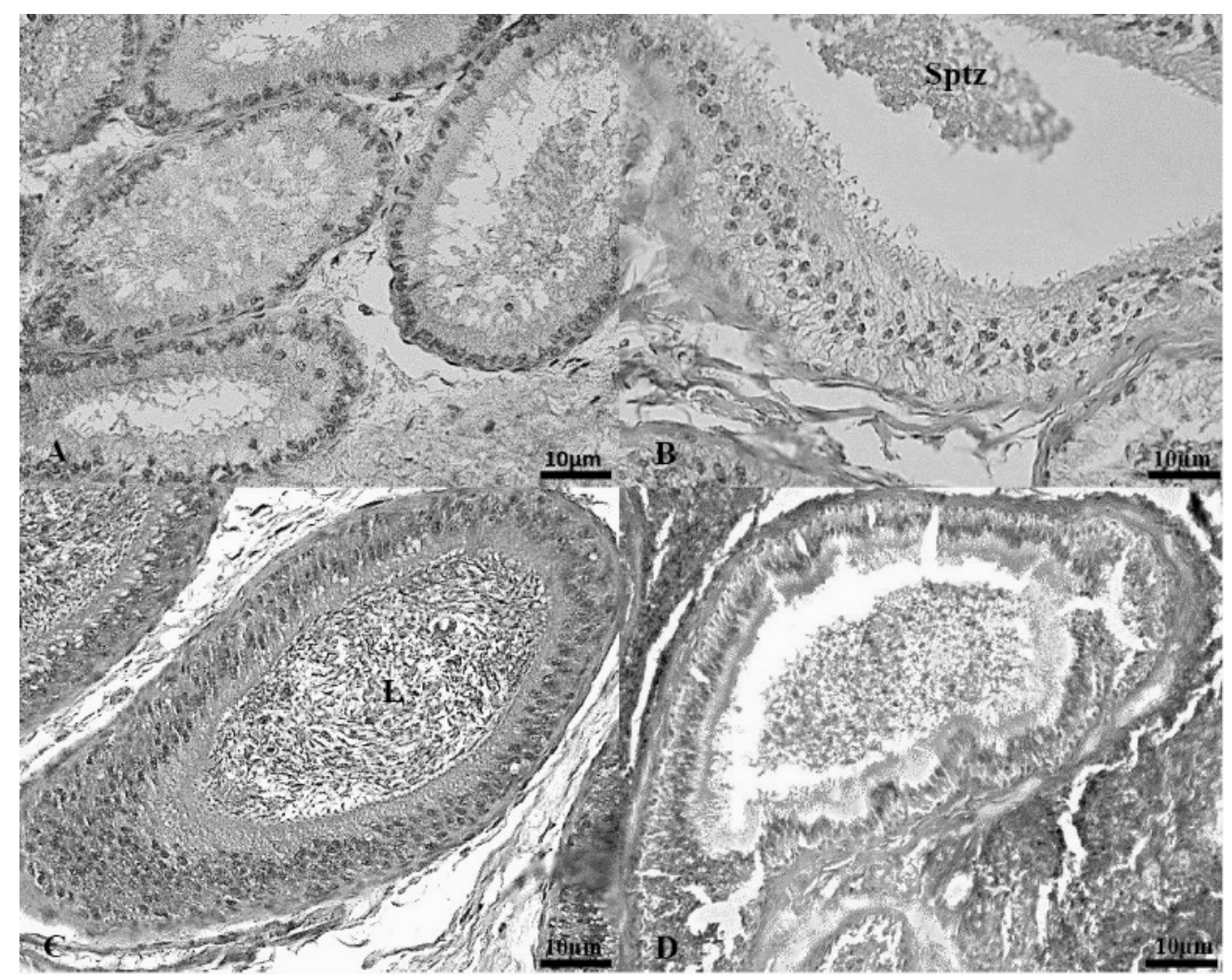

Figure 2 - Photomicrography of the epididymal tubules of the P. tajacu. A- Proximal caput epididymis; B- Distal caput epididymis: spermatozoa (Sptz) stored in one tubule; CCorpus epididymis: lumen (L) completely full of spermatozoa; D- Caudal epididymis 
In the proximal caput epididymis, basal and principal cells were less visible than in the other regions. Nucleus of principal cells changed throughout the epididymal regions; they were nearer to the basal lamina in the proximal caput epididymis. In the other regions, the nucleus was in the apical region. Muscle fibers, present in the intertubular space, were found in small quantities in the proximal caput epididymis. However, there was a progressive increase of these fibers throughout each region of the organ; they were visible in large quantities in the caudal epididymis.

Thirteen different types of morphological alterations (Table 3) were found on the analyzed epididymal spermatozoa $(\mathrm{n}=10,920)$ : minor sperm defects (16.73\%) and major sperm defects (23.20\%), according to Blom (1973).

Analyses of the sperm morphology associated with the epididymis according to the Mann-Whitney test, found no statistical difference $(\mathrm{P}>0.05)$ between minor and major defects (proximal head: $U=19.500$; distal head: $U=31.500$ body: $U=27.000$; and tail: $U=20.000$ ) (Figure 3).

\section{Discussion}

The proximal caput was the region presenting the smallest tubule diameter and epithelial height out of the analyzed epididymis. These data are different from those found by Schimming et al. (2012) in Cavia porcellus and by Ibrahim and Singh (2014) in Camelus dromedarius, which contained higher epithelia in the caput; otherwise, the corpus and caudal epididymis were the shortest regions. Briz et al. (1993) observed in swine that the proximal caput epididymis also possessed greater means for epithelial height and luminal diameter. These authors inferred that the greater epithelial height in the proximal caput would facilitate spermatozoa passage to other epididymal regions, since the proximal caput is the nearest to the testicle.

Table 3 - Morphological analysis of spermatozoa found in different regions of the $P$. tajacu epididymis. Sptz=Spermatozoa; M.P.= midpiece. Belém, Pará - Brazil - 2015

\begin{tabular}{lcccc}
\hline Pathologies & Proximal caput & Distal caput & Corpus & Caudal \\
\hline Minor Sperm Defects & $207(7.77 \%)$ & $489(21.13 \%)$ & $276(10.05 \%)$ & $202(6.31 \%)$ \\
Detached heads & $126(4.73 \%)$ & $80(3.45 \%)$ & $135(4.91 \%)$ & $215(6.71 \%)$ \\
Distal cytoplasmic droplet & $39(1.46 \%)$ & $12(0.51 \%)$ & $21(0.65 \%)$ & $31(1.12 \%)$ \\
Looped tail & $58(2.17 \%)$ & $32(1.38 \%)$ & $44(1.60 \%)$ & $30(0.93 \%)$ \\
Macrocephalic sperm & $6(0.22 \%)$ & $0(0 \%)$ & $0(0 \%)$ & $7(0.21 \%)$ \\
Bent tail with droplet & & & & \\
Major Sperm Defects & $519(19.49 \%)$ & $417(18.02 \%)$ & $487(17.74 \%)$ & $456(14.25 \%)$ \\
Underdeveloped Sptz & $168(6.31 \%)$ & $69(2.98 \%)$ & $105(3.82 \%)$ & $156(4.8 \%)$ \\
Proximal cytoplasmic droplet & $16(0.60 \%)$ & $2(0.08 \%)$ & $1(0.03 \%)$ & $5(0.18 \%)$ \\
Abnormal insertion of M.P. & $15(0.56 \%)$ & $9(0.38 \%)$ & $3(0.10 \%)$ & $3(0.09 \%)$ \\
Teratoids & $14(0.52 \%)$ & $28(1.21 \%)$ & $0(0 \%)$ & $5(0.18 \%)$ \\
Dag defects & $6(0.22 \%)$ & $15(0.64 \%)$ & $5(0.18 \%)$ & $8(0.25 \%)$ \\
Pseudo droplet & $3(0.11 \%)$ & $0(0 \%)$ & $0(0 \%)$ & $18(0.56 \%)$ \\
Decapitated sperm head & $1(0.03 \%)$ & $0(0 \%)$ & $0(0 \%)$ & $0(0 \%)$ \\
Denuded M.P. & 2662 & 2314 & 2744 & 3200 \\
\hline Total of analyzed Sptz & & & & \\
\hline
\end{tabular}






Figure 3 - Photomicrography of $P$. tajacu epididymal spermatozoa. A- Normal sperm; B- Immature sperm; C- Proximal cytoplasmic droplet (arrow); D- Distal cytoplasmic droplet (arrow); E- Simple bent tail with retention of cytoplasmic material; F- Teratoids (double tail). 1000x

However, changes in diameter of the tubules and epithelial heights are related to potential for cellular maturation and storage during transportation of spermatozoa through the organ. This is, in fact, due to the period in which spermatozoa are in transit, where tissue fluid changes occur, leading to absorption and activation of epithelial cell functions (DACHEUX et al., 2003; SRIVASTAV et al., 2004; TULSIANI, 2006). According to Crabo (1965), the many activities that occur in the epididymis promote spermatozoa maturation, and the caudal epididymis may improve the maximum survival time of the spermatozoon.

Thus, as noted in this paper, it was expected that smaller tubular diameters would be found in the ducts forming the proximal caput epididymis, which unite to form a single duct. The presence of larger tubules, with wide lumen in caudal epididymis, suggests that this region potentially contributes to spermatozoon storage in P. tajacu.

Overall, the coating epithelium of the epididymal duct of mammals contains several cell types: principal, basal and apical (CLELAND, 1957; ORSI et al., 1984; ARRIGHI et al., 1993; SCHIMMING et al., 2012). Similarly, in this research, basal and principal cells were found in all regions of the P. tajacu epididymis.

Although there was no statistical difference between the major and minor defects in all of the epididymal regions, underdeveloped spermatozoa stand out by their occurrence in greater numbers here than in the other pathologies. This problem is related to spermatogenesis. It may be that nutritional and hormonal problems, possibly connected to factors related to behavioral stress (due to the animals probably belonging to a lower hierarchical position in 
the social structure), are interfering with this process. Therefore, it is suggested that other reproductive and behavioral studies investigate this problem further.

Briz et al. (1993) observed that the caput epididymis of the Sus domesticus is characterized by the presence of distal cytoplasmic droplets and by mature spermatozoa, and the caudal epididymis by mature spermatozoa. However, in the present research, distal cytoplasmic droplets were found mainly in the caudal epididymis, while in the proximal caput, distal caput and corpus epididymis, a large quantity of detached heads and underdeveloped spermatozoa were observed.

The detached heads may be an artifact of the maceration technique used in this research. Olugbenga and Oniovosa (2005) used the maceration method in the same regions (proximal caput, distal caput and corpus epididymis) and retrograde flow in the caudal epididymis of Sus scrofa scrofa and observed the following pathologies: detached head and bent tail in the caput and corpus; detached head and looped tail in the caudal.

In terms of distal cytoplasmic droplets, Bezerra et al. (2014) observed in spermatozoa collected in the caudal epididymis of $P$. tajacu that it represented $29.6 \%$ of the total of analyzed cells. Although this pathology is frequently associated with this region (BEDFORD, 1963), this value was higher than that verified in the present research (6.71\%). However, when samples were subjected to centrifugation, this value decreased to

\section{References}

ARRIGHI, S.; ROMANELLO, M. G.; DOMENEGHINI, C. Ultrastructure of epididymal epithelium in Equus caballus. Annals of Anatomy, v. 175, n. 1, p. 1-9, 1993. doi: 10.1016/S0940-9602(11)80229-3.

BEDFORD, J. M. Morphological changes in rabbit spermatozoa during passage through the epididymis. Journal of Reproduction and Fertility, v. 5, p. 169-177, 1963. doi: 10.1530/jrf.0.0050169.
7.8\%. The cited authors believed that this process would lead to cytoplasmic membrane rupture of the droplets and content drainage.

Histological aspects of the different regions of the $P$. tajacu epididymis are similar to those of swine regarding the type of tissue and distribution. Nevertheless, as reported in this paper, particularities were found throughout the organ.

The spermatozoa morphology study is an important aspect in evaluating fertility and may indicate a relationship with possible problems related to behavioral stress of gregarious animals, such as the collared peccary. Morphological analysis of $P$. tajacu spermatozoa has indicated similarities to other artiodactylous species previously described in the literature. The present paper provides a baseline for future comparative research on the reproductive biology of artiodactyls that could contribute to their conservation and production.

\section{Acknowledgements}

The authors are grateful to FAPESPA/CNPqPRONEM - ICAAF n'070/2014 for financial support. We extend our sincere thanks to Brazilian Agricultural Research Corporation/Embrapa Eastern Amazon and Laboratório de Técnicas Histológicas (ICB-UFPA), for logistical support. Also, thanks to the Coordenação de Aperfeiçoamento de Pessoal de Nível Superior CAPES for a Masters' scholarship. The authors thank Gail Young for assistance with helpful comments.

BEZERRA, J. A. B.; SILVA, A. M.; PEIXOTO, G. C. X.; SILVA, M. A.; OLIVEIRA, M. F.; SILVA, A. R. Influence of recovery method and centrifugation on epididymal sperm from collared peccaries (Pecari tajacu Linnaeus, 1758). Zoological Science, v. 31, n. 5, p. 338-342, 2014. doi: 10.2108/zs130149.

BLOM, E. The ultrastructure of some characteristic sperm deffects and a proposal for a new classification of the bull spermiogram. Nordican Veterinarer Medicine, v. 25, n. 7, p. 383-391, 1973. 
BODMER, R. E.; PUERTAS, P. Community-based comanagement of wildlife in the Peruvian Amazon. In: ROBINSON, J. G.; BENNETT, E. L. (Ed.). Hunting for sustainability in tropical forests. New York: Columbia University Press, 2000. p. 395-409.

BRIZ, M.; BONET, S.; FRADERA, A. A morphologic study of the ductus of the epididymis of Sus domesticus. Journal of Morphology, v. 215, n. 2, p. 183-193, 1993. doi: 10.1002/jmor.1052150206.

CARVALHAL, R.; CAGNOTTO, D. J.; DANIEL, R. J. Aspectos morfológicos dos testículos e funículos espermáticos de catetos. Brazilian Journal of Morphology Sciences, v. 17, n. 2, p. 178, 2000. Supplement.

CLELAND, K. W. The structure and function of the epididymis. I. The histology of the rat epididymis. Australian Journal of Zoology, v. 5, n. 3, p. 223-246, 1957. doi: 10.1071/ZO9570223.

CRABO, B. Studies on the composition of epididymal content in bulls and boars. Acta Veterinaria Scandinavica, v. 6, n. 5, p. 1-94, 1965. Supplement.

DACHEUX, J. L.; GATTI, J. L.; DACHEUX, F. Contribution of epididymal secretory proteins for spermatozoa maturation. Microscopy Research and Technique, v. 61, n. 1, p. 7-17, 2003. doi: 10.1002/jemt.10312.

DESBIEZ, A. L. J.; KEUROGHLIAN, A.; BEISIEGEL, B. M.; MEDICI, E. P.; GATTI, A.; MENDES PONTES, A. R.; CAMPOS, C. B.; TÓFOLI, C. F.; MORAES JÚNIOR, E. A.; AZEVEDO, F. C.; PINHO, G. M.; CORDEIRO, J. L. P.; SANTOS JUNIOR, T. S.; MORAIS, A. A.; MANGINI, P. R.; FLESHER, K.; RODRIGUES, L. F.; ALMEIDA, L. B. Avaliação do risco de extinção do cateto Pecari tajacu Linnaeus, 1758, no Brasil. Biodiversidade Brasileira, v. 2, n. 3, p. 74-83, 2012.

GARCIA, A. R.; KAHWAGE, P. R.; GUIMARÃES, D. A. A.; OHASHI, O. M. Chilled semen of captive collared peccaries (Pecari tajacu): effects of preservation at $17^{\circ} \mathrm{C}$ on semen quality. Journal of Agricultural Science and Technology, v. 2, n. 7A, p. 921-929, 2012.

HELLGREN, E. C.; SYNATZSKE, D. R.; OLDENBURG, P. W.; GUTHERY, F. S. Demography of a collared peccary population in South Texas. Journal Wild Management, v. 59, n. 1, p. 153163, 1995. doi: $10.2307 / 3809128$.

IBRAHIM, Z. H.; SINGH, S. K. Histological and morphometric studies on the dromedary camel epididymis in relation to reproductive activity. Animal Reproduction Science, v. 149, n. 3-4, p. 212-217, 2014. doi: 10.1016/j.anireprosci. 2014.07.012.
KAHWAGE, P. R.; GARCIA, A. R.; GUIMARÃES, D. A. A.; OHASHI, O. M.; LUZ-RAMOS, R. S.; DIAS, H. L. T.; ALBUQUERQUE, N. I.; BARTHA, M. M. P. Biometria testicular, eletroejaculação e características seminais de caititus, Tayassu tajacu Linnaeus, 1758 (Mammalia, Artiodactyla, Tayassuidae) mantidos em cativeiro na Amazônia Oriental. Acta Amazônica, v. 40, n. 4, p. 771-778, 2010. doi: 10.1590/S0044-59672010000400019.

KIKUCHI, K.; NAGAI, T.; KASHIWAZAKI, N.; IKEDA, H.; NOGUCHI, J.; SHIMADA, A.; SOLOY, E.; KANEKO, H. Cryopreservation and ensuing in vitro fertilization ability of boar spermatozoa from epididymides stored at $4^{\circ} \mathrm{C}$. Theriogenology, v. 50, n. 4, p. 615-623, 1998. doi: 10.1016/S0093-691X(98)00166-6.

MAYOR, P.; FENECH, M.; BODMER, R. E.; LOPEZ-BEJAR, M. 2006. Ovarian features of the wild collared peccary (Tayassu tajacu) from the northeastern Peruvian Amazon. General and Comparative Endocrinology, v. 147, n. 3, p. 268-275, 2006. doi: 10.1016/j.ygcen.2006.01.010.

OLUGBENGA, O. M.; ONIOVOSA, U. Spermiogram and morphological characteristics in testicular and epididymal spermatozoa of large white boar in Nigeria. International Journal Morphology, v. 23, n. 3, p. 235-239, 2005. doi: 10.4067/S0717-95022005000300008.

ORSI, A. M.; VICENTINI, C. A.; MELO, V. R.; DALL PAI, V.; GREGÓRIO, E. A. Sobre a morfologia da via seminífera extratesticular no bovino zebu (Bos indicus). II. Reexame da histologia regional do epidídimo. Ciência e Cultura, v. 36, n. 2, p. 263-268, 1984.

ROBAIRE, B.; HINTON, B. T.; ORGEBIN-CRIST, M. The epididymis. In: KNOBIL, E.; NEILL, J. D. (Ed.). Physiology of reproduction. 3. ed. London: CRC Press, 2006. p. 1071-1148.

SCHIMMING, B. C.; DOMENICONI, R. F.; TSE, M. C. P.; TSE, H. G.; ORSI, A. M. Morfologia do epidídimo de cobaio (Cavia porcellus) em diferentes fases do desenvolvimento pós-natal. Brazilian Journal of Veterinary Research and Animal Science, v. 49, n. 4, p. 307-317, 2012. doi: 10.11606/issn.16784456.v49i4p307-317.

SOWLS, L. K. Javelinas and other Peccaries: their biology, management and use. Texas: Texas A\&M University Press, 1997. $325 \mathrm{p}$.

SONNER, J. B.; MIGLINO, M. A.; SANTOS, T. C.; CARVALHAL, R.; NETO, A. C. A.; MOURA, C. E. B.; OLIVEIRA, M. F. Aspectos macroscópicos e morfométricos dos testículos em catetos e queixadas. Biota Neotropica, v. 4, n. 2, p. 1-13, 2004. doi: 10.1590/S1676-06032004000200006. 
SRIVASTAV, A.; SINGH, B.; CHANDRA, A.; JAMAL, F.; KHAN, M. Y.; CHOWDHURY, S. R. Partial characterization, sperm association and significance of $\mathrm{N}$ - and O-linked glycoproteins in epididymal fluid of rhesus monkeys (Macaca mulatta). Reproduction, v. 127 , n. 3, p. 343-357, 2004. doi: 10.1530/rep.1.00119.

SULLIVAN, R. Male fertility markers, myth or reality. Animal
Reproduction Science, v. 82- 83, p. 341-347, 2004. doi: 10.1016/j.anireprosci.2004.05.007.

TULSIANI, D. R. P. Glycan-modifying enzymes in luminal fluid of the mammalian epididymis: an overview of their potential role in sperm maturation. Molecular and Cellular Endocrinology, v. 250, n. 1-2, p. 58-65, 2006. doi: 10.1016/j.mce.2005.12.025. 